\title{
Conformational landscape and low lying excited states of imatinib
}

\author{
Emil Vințeler • Nicoleta-Florina Stan • Raluca Luchian • \\ Călin Căinap • João P. Prates Ramalho • Vasile Chiș
}

Received: 1 December 2014 / Accepted: 22 February 2015 / Published online: 13 March 2015

(C) Springer-Verlag Berlin Heidelberg 2015

\begin{abstract}
The conformational changes of imatinib (IMT) are crucial for understanding the ligand-receptor interaction and its mechanism of action [Agofonov et al. (2014) Nature Struct Mol Biol 21:848-853]. Therefore, here we investigated the free energy conformational landscape of the free IMT base, aiming to describe the three-dimensional structures and energetic stability of its conformers. Forty-five unique conformers, within an energy window of $4.8 \mathrm{kcal} \mathrm{mol}^{-1}$ were identified by a conformational search in gas-phase, at the B3LYP/6-31G(d) theoretical level. Among these, the 20 most stable, as well as 4 conformers resulting from optimization of experimental structures found in the two known polymorphs of IMT and in the cAbl complex were further refined using the $6-31+G(d, p)$ basis set and the polarizable continuum solvation model. The most stable conformers in gas-phase and water exhibit a V-shaped structure. The major difference between the most stable free conformers and the bioactive conformers consists in the rela-
\end{abstract}

Electronic supplementary material The online version of this article (doi:10.1007/s00894-015-2639-8) contains supplementary material, which is available to authorized users.

E. Vințeler · N.-F. Stan • R. Luchian · V. Chiș $(\bowtie)$

Faculty of Physics, Babeș-Bolyai University,

1 Kogălniceanu, 400084 Cluj-Napoca, Romania

e-mail: vasile.chis@phys.ubbcluj.ro

C. Căinap

The Oncology Institute "Prof. Dr. Ion Chiricuță",

400015 Cluj-Napoca, Romania

J. P. P. Ramalho

Department of Chemistry, School of Science and Technology,

University of Évora, Rua Romão Ramalho, 59,

7000-671 Évora, Portugal

J. P. P. Ramalho

CGE-Centro de Geofisica de Evora, University of Évora,

Rua Romão Ramalho, 59, 7000-671 Évora, Portugal tive orientation of the pyrimidine-pyridine groups responsible for hydrogen bonding interactions in the ATP-binding pocket. The ratio of mole fractions corresponding to the two known $(\alpha$ and $\beta$ ) polymorphic forms of IMT was estimated from the calculated thermochemical data, in quantitative agreement with the existing experimental data related to their solubility. The electronic absorption spectrum of this compound was investigated in water and explained based on the theoretical TD-DFT results, considering the Boltzmann populationaveraged computed data at CAM-B3LYP/6-31+G(d,p) level of theory for the nine most stable conformers.

Keywords Imatinib $\cdot$ Conformational landscape $\cdot$ UV-vis · TD-DFT

\section{Introduction}

Imatinib, which has the IUPAC name 4-[(4-methylpiperazin1-yl)methyl]-N-(4-methyl-3-\{[4-(pyridin-3-yl)pyrimidin-2yl]amino phenyl)benzamide (IMT or STI-571, see Fig. 1), is a first generation tyrosine-kinase inhibitor (TKI), used mainly in the treatment of chronic myelogenous leukemia and gastrointestinal stromal tumors [1-8]. It acts selectively on Abl tyrosine kinases [9-11], mast/stem cell growth factor receptor (cKit) and platelet-derived growth factor receptors (PDGF-R) $[12,13]$. Very recently, Halperin et al. [14] demonstrated potential activity of IMT in combination with dacarbazine and capecitabine for treating endocrine cancers.

In spite of the high expectations related to the efficiency of this compound, a few drawbacks have been noted recently for IMT: protonations at nitrogen atoms as a result of $\mathrm{pH}$ changes [15], binding to plasma proteins in a large proportion [16, 17] and also a differential sensitivity of patients or the development of a resistance to the drug for patients under treatment $[11,13]$. 

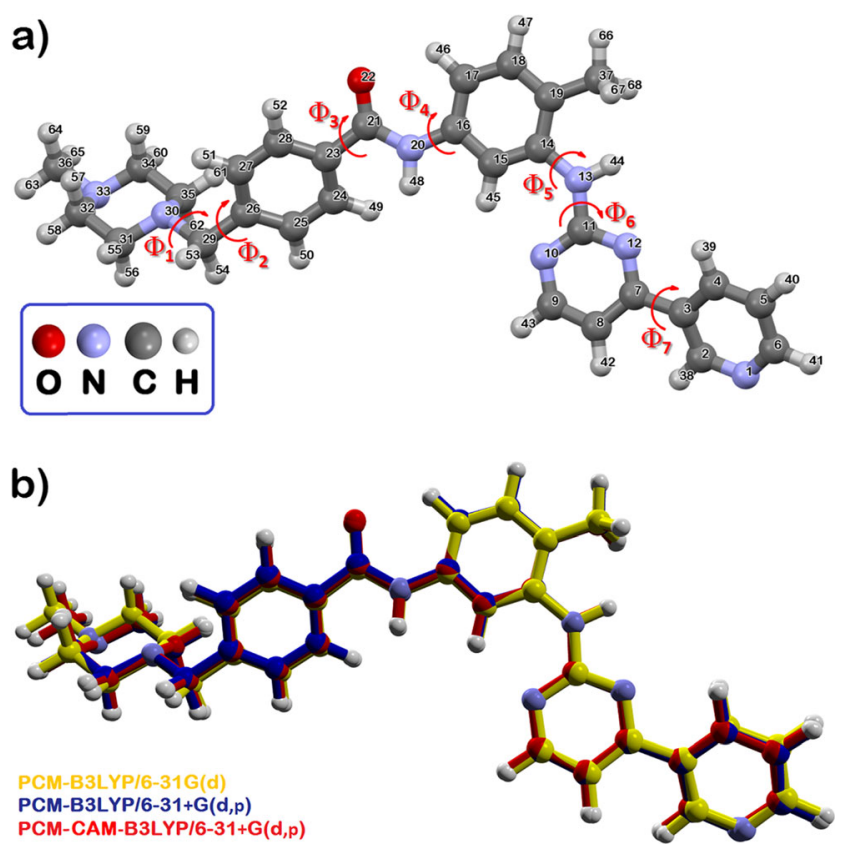

Fig. 1 a Optimized molecular structures of the most stable conformer of imatinib (IMT) in water (5) at polarizable continuum model (PCM)B3LYP/6-31+G(d,p) level of theory, with the atom numbering scheme. b Superimposed optimized structures of the most stable conformer of IMT in water (5) at three levels of theory, as indicated in the bottom left corner

Based on quantum chemical methods, recent works have addressed the interaction of IMT with Abl TK or calixarenes aiming at clarifying its mechanism of action [17-21] or at designing suitable drug carriers for TKIs [15, 22]. For such purposes, the accurate description of the three-dimensional (3D) arrangement and molecular properties of thermally accessible conformational states is crucial $[9,10,18,19,21$, 23-25]. Furthermore, analysis of the possible conformers of a particular drug molecule is mandatory for describing its spectroscopical properties reliably [26-31]. This is because, in general, the spectroscopic responses of molecules are due to the collective contributions of their conformers with relative energies in a narrow range of less than $1 \mathrm{kcal} \mathrm{mol}^{-1}$. Such behavior is obviously expected also for IMT.

Recently reported X-ray data show that IMT crystallizes in two polymorphic forms, $\alpha$ and $\beta$, with triclinic P-1 symmetry $[17,32]$. From a spectroscopic point of view, IMT was studied previously by FT-IR and FT-Raman [33], NMR [34], mass spectrometry [35-37], HPLC [38-43], capillary electrophoresis $[44,45]$ as well as by UV-vis in different solvents $[17,32$, 33, 46-48]. Surprisingly, in spite of the importance of conformational space, to the best of our knowledge, only scarce data related to the conformers of IMT have been reported in the literature $[19,23]$. Due to its high flexibility, IMT is expected to adapt easily to different environments. Moreover, as pointed out by Agafonov et al. [49], not only the drug, but the protein itself undergoes structural changes during and after binding. For this reason, besides the conformational landscape, another interest was to compare the 3D structure of the bioactive conformations found in different IMT-tyrosine kinases complexes $[9,10,18,23]$ to that of other possible conformers.

This is why we were interested in the possible conformers of IMT and their energetic orders. Thus, in the present work we identified 20 conformers of IMT in water in a relative Gibbs energy window of $1.69 \mathrm{kcal} \mathrm{mol}^{-1}$. Subsequently, the most stable nine structures whose relative energies are less than room temperature energy $\left(0.592 \mathrm{kcal} \mathrm{mol}^{-1}\right)$ were used to compute the electronic excitation energies, which in turn were used to explain the experimental observations.

A UV-vis study was conducted to check if the theoretically identified (most stable) conformers can explain the experimental observations. Moreover, this spectroscopic technique is (routinely) used to investigate the photosenzing properties of drugs [50], to identify their possible polymorphic forms [33] or to study the pharmacokinetic and pharmacodynamic properties of drugs in patients [51-53]. For these reasons, a reliable assignment of experimental electronic absorption data is highly needed, which in this study is given in terms of IMT monomeric structures.

\section{Methods}

\section{Experimental details}

Imatinib was purchased from a standard commercial source (Cayman Chemical, https://www.caymanchem.com) and used without further purification. UV-vis spectra of IMT in water were recorded at room temperature using a Jasco V-670 UVVis-NIR spectrophotometer (http://www.jascoinc.com) with a slit width of $2 \mathrm{~nm}$, in a quartz cuvette of $1-\mathrm{cm}$ path length.

\section{Computational details}

The conformational space of IMT was explored initially with Tinker software, using the MMFF94 molecular mechanics force field [54], which was developed based on quantum mechanics methods with the specific aim of being used in pharmaceutical science for predicting molecular geometries, conformational energies and energetics of drug-receptor interactions [55-58].

A systematic conformation search was performed using the MMFF94 molecular mechanics force field via Tinker software (convergence criterion was chosen to the default value of $\left.10^{-4} \mathrm{kcal} \mathrm{mol}^{-1} \AA^{-1}\right)$. In this way, we identified 4,024 conformations of IMT within an energy window of $34 \mathrm{kcal} \mathrm{mol}^{-1}$.

For the next part of the study we used the hybrid B3LYP exchange-correlation functional [59-62] in conjunction with Pople's "spectroscopic" 6-31G(d) (BS1) and 6-31+G(d,p) 
(BS2) basis sets [63]. The first 45 most stable conformers, whose relative free energies are less than $3.5 \mathrm{kcal} \mathrm{mol}^{-1}$ were subsequently re-optimized in gas-phase at B3LYP/BS1 level of theory. Besides these, we also optimized the geometries of IMT conformers found in the two known polymorphic forms and in c-Abl kinase complexes, using their solid state structures as starting geometries. A total number of 49 conformers were optimized, whose relative energy spans a free energy interval from 0 to $4.80 \mathrm{kcal} \mathrm{mol}^{-1}$. Finally, the gasphase structures were re-optimized in water at B3LYP/BS1 and B3LYP/BS2 levels of theory, using the PCM continuum solvation model [64]. Table 1 and Fig. 2 present the first nine

Table 1 Polarizable continuum model (PCM)-B3LYP/6-31G+(d,p) calculated dihedral angles (degrees) characterizing the nine most stable imatinib (IMT) conformers in water

\begin{tabular}{|c|c|c|c|c|c|c|c|c|}
\hline Conformer & $\Phi_{1}$ & $\Phi_{2}$ & $\Phi_{3}$ & $\Phi_{4}$ & $\Phi_{5}$ & $\Phi_{6}$ & $\Phi_{7}$ & $\theta, \alpha, \beta^{\mathrm{a}}$ \\
\hline T-A-C-C-C-C+T- (5) & -166.8 & -129.0 & -29.0 & -3.6 & 1.2 & 0.7 & -155.8 & $\begin{array}{l}132.2 \\
21.6 \\
50.9\end{array}$ \\
\hline $\mathrm{T}-\mathrm{G}+\mathrm{C}+\mathrm{C}+\mathrm{C}-\mathrm{C}+\mathrm{C}+(16)$ & -167.6 & 52.8 & -29.3 & -6.7 & -0.1 & -0.4 & 24.7 & $\begin{array}{l}95.7 \\
20.4 \\
76.9\end{array}$ \\
\hline $\mathrm{T}-\mathrm{G}+\mathrm{C}+\mathrm{C}+\mathrm{C}-\mathrm{C}+\mathrm{C}-(13)$ & -167.5 & 54.2 & -28.7 & -6.4 & -0.2 & -0.8 & -24.6 & $\begin{array}{l}96.5 \\
-21.3 \\
45.4\end{array}$ \\
\hline $\mathrm{T}-\mathrm{G}+\mathrm{C}-\mathrm{C}-\mathrm{C}+\mathrm{C}+\mathrm{T}+(6)$ & -167.6 & 54.5 & -28.4 & -6.3 & 3.0 & 0.3 & 156.7 & $\begin{array}{l}95.3 \\
-16.1 \\
47.0\end{array}$ \\
\hline T-G+C-C-C-C-T- (3) & -167.5 & 53.9 & -28.8 & -6.4 & 1.6 & 0.2 & -156.4 & $\begin{array}{l}95.3 \\
21.4 \\
45.4\end{array}$ \\
\hline $\mathrm{G}-\mathrm{A}+\mathrm{C}+\mathrm{C}+\mathrm{C}+\mathrm{C}-\mathrm{T}-(7)$ & -68.6 & 129.8 & 29.0 & 3.4 & -0.8 & -0.5 & -156.1 & $\begin{array}{l}130.8 \\
18.8 \\
50.0\end{array}$ \\
\hline $\mathrm{T}-\mathrm{G}+\mathrm{C}-\mathrm{C}-\mathrm{C}-\mathrm{T}+\mathrm{T}+(10)$ & -166.3 & 52.0 & -29.4 & -6.6 & -11.1 & 177.9 & 154.4 & $\begin{array}{l}30.1 \\
-35.7 \\
42.2\end{array}$ \\
\hline $\mathrm{T}-\mathrm{G}+\mathrm{C}-\mathrm{C}+\mathrm{C}+\mathrm{T}-\mathrm{T}-(18)$ & -167.1 & 54.2 & -27.5 & -4.5 & 5.8 & -177.0 & -153.1 & $\begin{array}{l}34.8 \\
31.9 \\
49.5\end{array}$ \\
\hline T-G+C-C-C+T-T- (14) & -167.1 & 54.2 & -27.5 & -4.5 & 5.8 & -177.0 & -153.1 & $\begin{array}{l}34.8 \\
26.1 \\
49.6\end{array}$ \\
\hline$\alpha$-form & -167.7 & 48.8 & -29.2 & 169.9 & -6.1 & -0.8 & -156.2 & $\begin{array}{l}149.0 \\
13.2 \\
38.8\end{array}$ \\
\hline$\beta$-form & -167.5 & 52.2 & 27.8 & 180.0 & -111.0 & -6.8 & 156.4 & $\begin{array}{l}123.0 \\
38.0 \\
71.0\end{array}$ \\
\hline A-c-Abl & -166.6 & 46.0 & 27.3 & -175.4 & 112.8 & 5.3 & 156.6 & $\begin{array}{l}120.7 \\
77.6 \\
83.6\end{array}$ \\
\hline B-c-Abl & -168.0 & 53.4 & 27.6 & -176.3 & 112.3 & 5.4 & -23.7 & $\begin{array}{l}116.8 \\
78.2 \\
66.2\end{array}$ \\
\hline
\end{tabular}

${ }^{\mathrm{a}}$ As defined in [19] 
Fig. 2 PCM-B3LYP/6-31+ $G(d, p)$ optimized structures of the nine most stable IMT conformers in water, together with $\alpha$ and $\beta$ crystal forms [32], as well as the $\mathrm{A}$ - and B-forms found in the kinase complex of c-Abl [71]

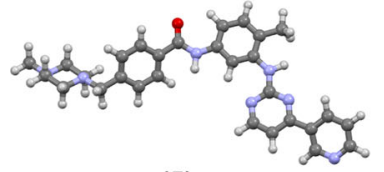

(5)

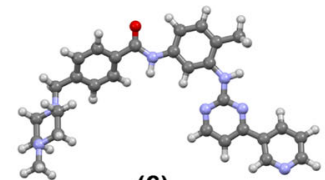

(6)

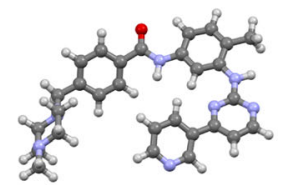

(10)

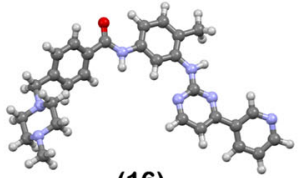

(16)

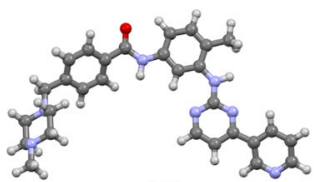

(3)

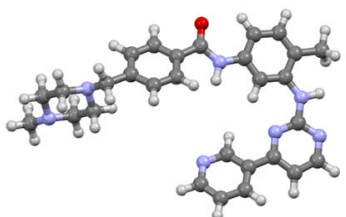

(18)

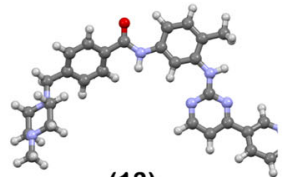

(13)

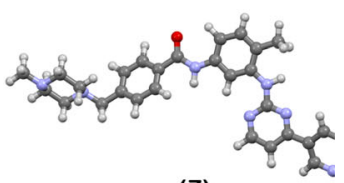

(7)

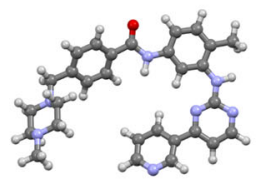

(14)

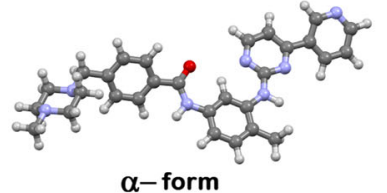

$\alpha-$ form

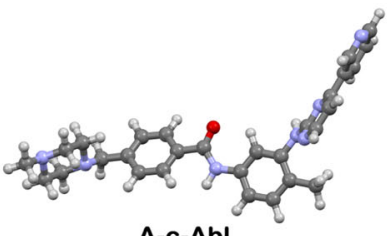

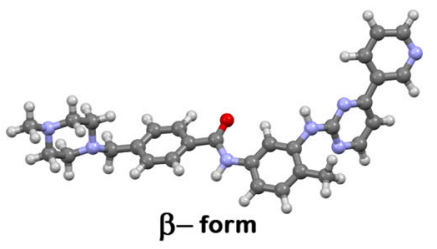

$\beta$-form

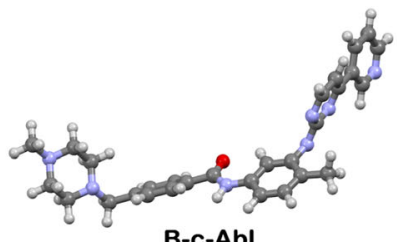

most stable conformers thus obtained, whose relative energies are less than the room temperature energy $\left(0.592 \mathrm{kcal} \mathrm{mol}^{-1}\right)$. For comparison purposes we also included the two optimized and experimental structures of the conformers found in the cAbl kinase complex and in the $\alpha$ and $\beta$ polymorphs.

Frequency calculations confirmed that all the optimized geometries correspond to minima on the potential energy surface (PES). The optimization of IMT geometry and calculations of vibrational frequencies were performed with the Gaussian09 software package [65].

Boltzmann weighting factors for each conformer were derived at room temperature $(\mathrm{T}=298 \mathrm{~K})$ by using the relative free energies $(\Delta \mathrm{G})$. The latter values were obtained from frequency calculations including thermal corrections to energies [66].

Absorption spectra of IMT were calculated using the timedependent DFT (TD-DFT) methodology [67] implemented in the Gaussian09 package, which describes the excited states in terms of all possible single excitations from occupied to virtual orbital. For this purpose we used the long-range corrected CAM-B3LYP functional [68] coupled to the 6-31+G(d,p) basis set, and the excitation energies were calculated on the IMToptimized structures at B3LYP/BS2 level of theory.
The simulated UV-vis spectrum of IMT in the 180$400 \mathrm{~nm}$ range has been obtained by summation of contributions from transitions to the first 80 singlet excited electronic states. The UV spectral line-shapes were convoluted with Gaussian functions with FWHM of $0.96 \mathrm{eV}$, as derived from experimental spectra.

Figures representing the structures of IMT were created using the Mercury 3.3 [69] and Molegro Molecular Viewer [70] program packages.

\section{Results and discussion}

Conformation landscape

Imatinib conformers can be generated by varying the torsion angle around seven rotatable bonds (see Fig. 1): N30-C29, C29-C26, C23-C21, N20-C16, C14-N13, N13-C11 and C7-C3. Table 1 summarizes the dihedral angles $\Phi_{1}-\Phi_{7}$ that characterize the 20 most stable conformers whose structures are shown in Fig. 2. Their names, relative Gibbs energies and populations are summarized in Table 2. Besides the 20 most 
Table 2 Relative free energies and Boltzmann populations of the 20 most stable conformers of imatinib in gas-phase [B3LYP/6-31G(d) level of theory] and in water [PCM-B3LYP/6-31G(d) and PCM-B3LYP/6-31+G(d,p) levels of theory] at room temperature

\begin{tabular}{|c|c|c|c|c|c|c|}
\hline \multirow[t]{2}{*}{ Conformer } & \multicolumn{2}{|c|}{ Gas-phase B3LYP/6-31G(d) } & \multicolumn{2}{|c|}{ Water PCM-B3LYP/6-31G(d) } & \multicolumn{2}{|c|}{ Water PCM-B3LYP/6-31+G(d,p) } \\
\hline & $\Delta \mathrm{G}^{\mathrm{a}}\left(\mathrm{kcal} \mathrm{mol}^{-1}\right)$ & Population (\%) & $\Delta \mathrm{G}^{\mathrm{b}}\left(\mathrm{kcal} \mathrm{mol}{ }^{-1}\right)$ & Population (\%) & $\Delta \mathrm{G}^{\mathrm{c}}\left(\mathrm{kcal} \mathrm{mol}^{-1}\right)$ & Population $(\%)$ \\
\hline G-A+C-C-C+C-T- (1) & 0.00 & 16.24 & 0.31 & 6.15 & 1.06 & 1.85 \\
\hline $\mathrm{G}-\mathrm{A}+\mathrm{C}-\mathrm{C}-\mathrm{C}+\mathrm{C}+\mathrm{T}-(2)$ & 0.40 & 8.38 & 0.35 & 5.75 & 1.07 & 1.83 \\
\hline T-G+C-C-C-C-T- (3) & 0.40 & 8.37 & 0.26 & 6.64 & 0.27 & 7.07 \\
\hline $\mathrm{G}-\mathrm{A}+\mathrm{C}-\mathrm{C}-\mathrm{C}+\mathrm{C}-\mathrm{T}+(4)$ & 0.44 & 7.82 & 0.14 & 8.12 & 0.66 & 3.67 \\
\hline T-A-C-C-C-C+T- (5) & 0.48 & 7.28 & 0.00 & 10.33 & 0.00 & 11.13 \\
\hline $\mathrm{T}-\mathrm{G}+\mathrm{C}-\mathrm{C}-\mathrm{C}+\mathrm{C}+\mathrm{T}+(6)$ & 0.69 & 5.16 & 0.35 & 5.74 & 0.26 & 7.22 \\
\hline $\mathrm{G}-\mathrm{A}+\mathrm{C}+\mathrm{C}+\mathrm{C}+\mathrm{C}-\mathrm{T}-(7)$ & 0.71 & 4.95 & 0.51 & 4.38 & 0.34 & 6.29 \\
\hline G-G-C-C-C+C+T- (8) & 0.72 & 4.84 & 0.85 & 2.49 & 0.65 & 3.72 \\
\hline $\mathrm{T}-\mathrm{G}+\mathrm{C}+\mathrm{C}+\mathrm{C}-\mathrm{C}+\mathrm{T}-(9)$ & 0.74 & 4.72 & 0.83 & 2.58 & 0.94 & 2.28 \\
\hline $\mathrm{T}-\mathrm{G}+\mathrm{C}-\mathrm{C}-\mathrm{C}-\mathrm{T}+\mathrm{T}+(10)$ & 0.97 & 3.22 & 0.16 & 7.86 & 0.41 & 5.57 \\
\hline $\mathrm{G}-\mathrm{A}+\mathrm{C}-\mathrm{C}-\mathrm{C}+\mathrm{C}-\mathrm{C}-(11)$ & 0.97 & 3.20 & 0.29 & 6.31 & 0.63 & 3.87 \\
\hline $\mathrm{T}-\mathrm{G}+\mathrm{C}+\mathrm{C}+\mathrm{C}+\mathrm{T}-\mathrm{T}-(12)$ & 0.97 & 3.19 & 1.18 & 1.45 & 0.78 & 3.00 \\
\hline $\mathrm{T}-\mathrm{G}+\mathrm{C}+\mathrm{C}+\mathrm{C}-\mathrm{C}+\mathrm{C}-(13)$ & 1.02 & 2.97 & 0.42 & 5.14 & 0.03 & 10.59 \\
\hline T-G+C-C-C+T-T- (14) & 1.04 & 2.87 & 0.47 & 4.73 & 0.49 & 4.84 \\
\hline $\mathrm{T}-\mathrm{G}+\mathrm{C}-\mathrm{T}+\mathrm{C}-\mathrm{T}+\mathrm{T}-(15)$ & 1.04 & 2.84 & 1.12 & 1.59 & 1.69 & 0.64 \\
\hline $\mathrm{T}-\mathrm{G}+\mathrm{C}+\mathrm{C}+\mathrm{C}-\mathrm{C}+\mathrm{C}+(16)$ & 1.05 & 2.83 & 0.15 & 8.07 & 0.03 & 10.63 \\
\hline $\mathrm{G}-\mathrm{A}+\mathrm{C}-\mathrm{C}-\mathrm{C}+\mathrm{C}-\mathrm{C}+(17)$ & 1.05 & 2.81 & 0.43 & 5.05 & 1.09 & 1.76 \\
\hline $\mathrm{T}-\mathrm{G}+\mathrm{C}-\mathrm{C}+\mathrm{C}+\mathrm{T}-\mathrm{T}-(18)$ & 1.05 & 2.79 & 0.48 & 4.66 & 0.49 & 4.86 \\
\hline T-A-C+C-C-T-C+ (19) & 1.06 & 2.77 & 1.13 & 1.56 & 0.98 & 2.13 \\
\hline G-A+C-C-C+T-T- (20) & 1.06 & 2.76 & 1.20 & 1.38 & 0.72 & 3.30 \\
\hline
\end{tabular}

${ }^{\text {a }}$ Relative to conformer (1)

${ }^{\mathrm{b}}$ Relative to conformer (5)

${ }^{\mathrm{c}}$ Relative to conformer (5)

stable conformers, Fig. 2 includes also the optimized conformations of IMT obtained by using as starting geometries the structures found in $\alpha$ and $\beta$ polymorphs [32] and two structures (A and $\mathrm{B}$ ) found in the c-Abl-imatinib complex [71].

To name the conformers we employed the usual terminology in polymer stereochemistry [72, 73], using the four letters $\mathrm{C}, \mathrm{G}$, $\mathrm{A}$ and $\mathrm{T}$, each followed by $\mathrm{a}+$ or - sign, depending on the value of the angle to which the letter is assigned (see Scheme S1). Namely, the particular value of each of the dihedral angles $\Phi_{1}-\Phi_{7}$ that define the conformation of IMT (see Fig. 1) contributes with a doublet formed from one letter and a ( + or -$)$ sign to the whole name of the conformer. Thus, with respect to a given bond and its associated dihedral angle, a conformer is: $\mathrm{C}-$ or $\mathrm{C}+(\mathrm{cis})$ type for an angle between $-30^{\circ}$ and $0^{\circ}$ or $0^{\circ}$ and $30^{\circ}$, respectively, $\mathrm{T}-$ or $\mathrm{T}+$ (trans) type for an angle between $-180^{\circ}$ and $-150^{\circ}$ or $150^{\circ}$ and $180^{\circ}$, respectively, G- or G+ (gauche) type for an angle between $-90^{\circ}$ and $-30^{\circ}$ or $30^{\circ}$ and $90^{\circ}$, respectively, or $\mathrm{A}-$ or $\mathrm{A}+$ (anticlinal) type for an angle between $-150^{\circ}$ and $-90^{\circ}$ or $90^{\circ}$ and $150^{\circ}$, respectively.

It is important to note here that, for IMT's conformers, there are two kind of structural transformations that do not affect their energies: the first is related to the rotation of the benzene ring along the $\mathrm{C} 23-\mathrm{C} 26$ axis, while keeping all the other dihedrals unchanged. Such transformations involve changes in the dihedrals $\Phi_{2} \rightarrow \mathrm{N} 30-\mathrm{C} 29-\mathrm{C} 26-\mathrm{C} 27$ and $\Phi_{3} \rightarrow \mathrm{C} 28-$ C23-C21-N20.

Another transformation that changes the structure, but not the energy, is a mirror symmetry, related to transformation of dihedral angle $\Phi_{1} \rightarrow \mathrm{C} 35-\mathrm{N} 30-\mathrm{C} 29-\mathrm{C} 26$ and the change of sign of the other six dihedral angles. To avoid counting the symmetry-related conformations, only those conformers that have the first dihedral angle negative and the third dihedral angle between -30 and $30^{\circ}$ are considered in Table 2 .

The conformational analysis shows that for each dihedral angle there are four different conformers. Because of the two symmetries mentioned above, the number of different conformers is $4^{7} /(2 \times 2)=4,096$, the theoretical maximum value being just a bit larger than 4,024 , the value obtained with Tinker software and the MMFF94 force field.

The most visible difference between the $\mathrm{C}$ and $\mathrm{T}$ type conformers can be observed between those containing these letters in the sixth doublet, i.e., differing in the rotation around the N13-C14 bond. The conformers with the sixth doublet as $\mathrm{C}-$ and $\mathrm{C}+$ have a V-shape, [19], while the conformers having 
the sixth doublet $\mathrm{T}-$ and $\mathrm{T}+$ are $\mathrm{U}$-shaped (see Fig. 2 and Tables 1 and S1). It is important to note that only conformer (15) (see Table S2) has an S-like shape, closest to that of the $\alpha$ and $\beta$ polymorphs and to the structures found in IMT-c-Abl complexes.

Special attention must be paid to the piperazine fragment of IMT, which is a radical of $\mathrm{N} \mathrm{N}^{\prime}$-dimethyl-piperazine. In the chair form of $\mathrm{N} \mathrm{N}^{\prime}$-dimethyl-piperazine, which, according to our calculations, is more stable than the skewed boat by $8.23 \mathrm{kcal} \mathrm{mol}^{-1}$ [relative Gibbs energy calculated at B3LYP/ 6-31G(d) level of theory], the two $\mathrm{N}-\mathrm{CH}_{3}$ bonds can remain equatorial or axial, leading to three different conformations, eq-eq, eq-ax and ax-ax, with relative Gibbs energy of 0.00 , 6.47 and $7.69 \mathrm{kcal} \mathrm{mol}^{-1}$, respectively. The most stable conformer in gas-phase (1) has the piperazine fragment in the chair form with eq-eq conformation. According to data presented in Table 1 and Fig. 2, the chair conformation is preserved for all IMT conformers considered within a relative Gibbs energy of $0.49 \mathrm{kcal} \mathrm{mol}^{-1}$.

As shown in Table 2, the first nine most stable conformers in water are dominant, constituting more than $68 \%$ of the Boltzmann population. The most stable conformer in gasphase is (1), while conformer (5) is the most stabilized in water; the main differences between the structures of the two conformers consist in the relative orientation of the piperazine group relative to the rest of the molecule (see Table S1). Such a difference is expected considering that this group represents the hydrophobic moiety of IMT [19]. The conformers (16), (13), (6), (3), (10), (18) and (24) are U-shaped molecules (see Fig. 2) with a value of $\theta$ angle below $97^{\circ}$. The $\alpha$ dihedral angle between the pyridine and methylbenzene rings has values between $50^{\circ}$ and $90^{\circ}$ in type II inhibitor-protein complexes, but for the first nine most stable free IMT conformers in Table $1, \alpha$ values oscillate between $-35^{\circ}$ and $32^{\circ}$ (see Table 1). The hydrogen interactions of the pyridine and pyrimidine groups of IMT with the aminoacids of the ATP pocket rotate the plane of these groups relative to the plane of the methylbenzene ring.

The $\beta$ dihedral angle between piperazine and the methylbenzene group is distributed largely between $0^{\circ}$ and $90^{\circ}$ in protein-imatinib complexes and the same happens for the free conformers, whose $\beta$ values are between $42^{\circ}$ and $77^{\circ}$ (see Table 1).

Table 3 lists the experimental dihedral angles of IMT as found in the c-Abl kinase complex [71], but also the $\alpha$ and $\beta$ polymorphic forms [32] (see their structures in Fig. 2). The dihedral angle $\Phi_{5}$ for IMT in tyrosine kinase complex is $97.5^{\circ}$, giving rise to a value of $92.6^{\circ}$ for the $\alpha$ angle, characteristic for type II inhibitors. There is also a large value of 77.7 and $-113.3^{\circ}$ of dihedral angle $\Phi_{5}$ in the $\alpha$ and $\beta$ crystal form, respectively. In contrast, according to the data presented in Table 1, this dihedral in the free conformers in water with relative Gibbs energies less than $0.592 \mathrm{kcal} \mathrm{mol}^{-1}$ is limited to small values between $-11.1^{\circ}$ and $-5.8^{\circ}$. The hydrogen bonding interactions of IMT in the tyrosine kinase complex and in the mesylate crystal constrain the molecule to a less stable conformer with larger relative Gibbs energy than the isolated counterpart in water, by $1.60-1.77 \mathrm{kcal} \mathrm{mol}^{-1}$. Notably, only conformer (15) has an S-like shape, resembling the conformation found in both solid state polymorphs [32] and the c-Abl-IMT complex [71]. Moreover, from Fig. 2 it is evident that the major difference between the structures of the free V-shape conformers and the bioactive conformer bound to $\mathrm{c}-\mathrm{Abl}$ kinase consists of the relative orientation of the pyrimidine-pyridine groups. It is this moiety through which the IMT ligand binds to the ATP pocket of TK.

To conclude the discussion about the structural features of IMT conformers, we would like to note that the BS1 basis set was demonstrated as a good compromise for obtaining optimized geometries, relative energies and even excitation
Table 3 Experimental and PCM-B3LYP/6-31+G(d,p)-calculated dihedral angles (degrees) and relative free energy characterizing the IMT $\alpha$ and $\beta$ crystal forms [22] and the A-form and B-form in the tyrosine kinase complex [59] and their optimized conformers in water.
Exp. Experimental data, Opt. Optimized; $A, B$ The two forms found in cAbl kinase complexes with IMT [59]; $\alpha, \beta$ the two structures determined in the $\alpha$ and $\beta$ polymorphs of imatinib [22]

\begin{tabular}{|c|c|c|c|c|c|c|c|c|}
\hline & $\Delta \mathrm{G}^{\mathrm{a}}$ & $\Phi_{1}$ & $\Phi_{2}$ & $\Phi_{3}$ & $\Phi_{4}$ & $\Phi / 5$ & $\Phi_{6}$ & $\Phi_{7}$ \\
\hline Exp. A [59] & n.a. ${ }^{b}$ & -179.0 & 49.4 & 15.7 & -176.6 & 97.5 & -0.5 & 170.3 \\
\hline Opt.-A water & 1.77 & -166.6 & 46.0 & 27.3 & -175.4 & 112.8 & 5.3 & 156.6 \\
\hline Exp. B [59] & n.a. & -179.8 & 49.4 & 24.6 & -179.8 & 97.5 & -0.5 & -12.1 \\
\hline Opt.-B water & 1.60 & -168.0 & 53.4 & 27.6 & -176.3 & 112.3 & 5.4 & -23.7 \\
\hline Exp. $\alpha[22]$ & n.a. & -165.7 & 43.5 & -25.8 & -164.6 & 77.9 & -26.9 & 36.6 \\
\hline Opt. $\alpha$ water & 1.19 & -167.7 & 48.8 & -29.2 & -168.7 & -6.1 & -0.8 & 24.4 \\
\hline Exp. $\beta$ [22] & n.a. & -168.3 & 23.7 & 35.3 & -129.2 & -113.3 & -3.9 & -13.2 \\
\hline Opt. $\beta$ water & 1.47 & -167.5 & 52.2 & 27.8 & -0.6 & -111.0 & -6.8 & -24.1 \\
\hline
\end{tabular}

${ }^{\text {a }}$ Relative to conformer (5)

${ }^{\mathrm{b}}$ Not available 
energies, at least for small or medium-sized molecules [74-80]. Such properties are somehow "system dependent", i.e., in some cases the experimentally derived properties are accurately reproduced even with a small basis set like 6$31 \mathrm{G}(\mathrm{d})$. For spatially extended molecules like IMT, the relative conformational energies could be affected significantly by using more flexible basis sets.

However, as shown in Fig. 1b, slight differences were noted between the geometries of the conformer (5) obtained by using the two basis sets. Actually, the only significant differences were observed for the relative orientations of the $\mathrm{CH}_{2}$-benzene and pyridine-pyrimidine groups. Thus, the $\Phi_{1}$ and $\Phi_{7}$ dihedrals change from $-140.4^{\circ}$ and $-161.2^{\circ}$, to $-129.0^{\circ}$ and $-155.8^{\circ}$, respectively. The effect of the xc functional on geometries was tested for conformer (5) only. We observed that the influence was marginal, the largest difference between the B3LYP and CAM-B3LYP functionals (of $1.82^{\circ}$ ) being observed for the $\Phi_{2}$ angle that describes the orientation of the methylene $\mathrm{CH}_{2}$ group relative to the benzene moiety.
Quantitatively, for this conformer, the average root mean square deviation (rmsd) between the backbone atoms in case of the B3LYP functional coupled to the two basis sets was $0.192 \AA$, while the rmsd between B3LYP and CAM-B3LYP functionals, both coupled to the BS2 basis set, was $0.035 \AA$.

On the other hand, the basis set drastically affects the relative stability of the conformers. Thus, as seen in Table S2, the energetic order of the conformers with relative free energy within the room temperature energy is (5), (4), (16), (10), (3), (11), (1), (2), (6), (13), (17), (14), (18), (7) for BS1, but it changed to (5), (16), (13), (6), (3), (7), (10), (18), (14) in case of the BS2 basis set. The total relative population of these two sets of conformers also changed from 85.61 to $68.21 \%$.

Regarding the two polymorphic forms of IMT, it is possible to estimate the difference in fusion enthalpies between two polymorphic forms as the difference between the enthalpies of conformers in gas-phase [81, 82]. Thus, for an ideal solution, the mole fraction $\mathrm{x}$ of solute at saturation is a function of fusion enthalpy $\Delta \mathrm{H}$, molar heat capacity $\Delta \mathrm{C}_{\mathrm{p}}$, the melting temperature $T_{\mathrm{m}}$ and the temperature $T$ of the solution [81]:

$\mathrm{x}=\exp \left(-(\Delta \mathrm{H} / \mathrm{R}) \cdot\left(1 / \mathrm{T}-1 / \mathrm{T}_{\mathrm{m}}\right)+\left(\Delta \mathrm{C}_{\mathrm{p}} / \mathrm{R}\right) \cdot\left(\left(\mathrm{T}_{\mathrm{m}}-\mathrm{T}\right) / \mathrm{T}+\ln \left(\mathrm{T} / \mathrm{T}_{\mathrm{m}}\right)\right)\right)$

For IMT, the difference in fusion enthalpy is estimated as $\mathrm{H}_{\beta}-\mathrm{H}_{\alpha}=2.45 \mathrm{~kJ} \mathrm{~mol}^{-1}$ and the difference in molar heat capacity $\Delta \mathrm{C}_{\mathrm{p}}$ is approximated by the difference in fusion entropy $\left(\Delta \mathrm{S}_{\beta}-\Delta \mathrm{S}_{\alpha}=-3.67 \mathrm{~J} \mathrm{~K}^{-1} \mathrm{~mol}^{-1}\right)$ for transition from crystal form to supercooled liquid form (that is calculated for the two polymorphic states $\alpha$ and $\beta$ as $\Delta \mathrm{S}=\mathrm{S}_{\mathrm{gas}}-\mathrm{S}_{\mathrm{water}}$ ). For estimating the $\mathrm{x}_{\alpha} / \mathrm{x}_{\beta}$ ratio we used the equation:

$\mathrm{x}_{\alpha} / \mathrm{x}_{\beta}=\exp \left(\left(\mathrm{H}_{\beta}-\mathrm{H}_{\alpha}\right) / \mathrm{R} \cdot\left(1 / \mathrm{T}-1 / \mathrm{T}_{\mathrm{mm}}\right)-\left(\Delta \mathrm{S}_{\beta}-\Delta \mathrm{S}_{\alpha}\right) / \mathrm{R} \cdot\left(\left(\mathrm{T}_{\mathrm{m}}-\mathrm{T}\right) / \mathrm{T}+\ln \left(\mathrm{T} / \mathrm{T}_{\mathrm{mm}}\right)\right)\right)$

where $T_{\mathrm{mm}}=494.5 \mathrm{~K}$ is the average value of the experimental melting temperatures of the two polymorphs [32]. Using the above equation and estimations we obtained at room temperature $(T=298 \mathrm{~K})$ a value of 2.26 for the ratio of mole fractions, in excellent agreement with experimental finding that $\alpha$-form polymorph is 2.5 times more soluble than the $\beta$-form.

In addition, considering the difference in experimental fusion enthalpies between $\beta$ and $\alpha$ forms of $3.18 \mathrm{~kJ} \mathrm{~mol}^{-1}$ [32] our calculations predict that $2.45 \mathrm{~kJ} \mathrm{~mol}^{-1}$ is due to conformational difference and $0.73 \mathrm{~kJ} \mathrm{~mol}^{-1}$ is due to the difference of the Van der Waals interactions in crystal.

UV-vis spectra

Figure 3 illustrates the evolution of the UV-vis spectrum of IMT in water as a function of concentration within the $10^{-5}$ $10^{-4} \mathrm{M}$ range. While a clear red-shift of the peak around 195 $203 \mathrm{~nm}$ is observed by increasing the concentration, the other two absorbance peaks at 237 and $257 \mathrm{~nm}$ do not change their positions. By increasing the concentration, a slight bathochromic shift and hypochromism is observed for the peak around $200 \mathrm{~nm}$. These effects are most probably a result of the interaction between the solute and solvent molecules [83-85].

The absorption peak at $257 \mathrm{~nm}$ was observed in other solvents between 258 and $268 \mathrm{~nm}$ in water at a different $\mathrm{pH}$ [17], at $277 \mathrm{~nm}$ in methanol [8,33], at $273 \mathrm{~nm}$ in ethanol [17] and at $275 \mathrm{~nm}$ in acetonitrile [50].

Recently reported data demonstrated that for molecules with large spatial extent, the calculated electronic transition energies can be improved significantly by using the longrange corrected CAM-B3LYP functional [86-91]. For this reason, we decided to calculate the UV-vis spectrum of IMT at CAM-B3LYP/BS2//B3LYP/BS2 level of theory.

For concentrations lower than $10^{-4} \mathrm{M}$ it is assumed that the monomers contribute predominantly to the absorption spectrum in solution. Due to the small relative Gibbs energies of the conformers it is expected that the experimental spectrum 


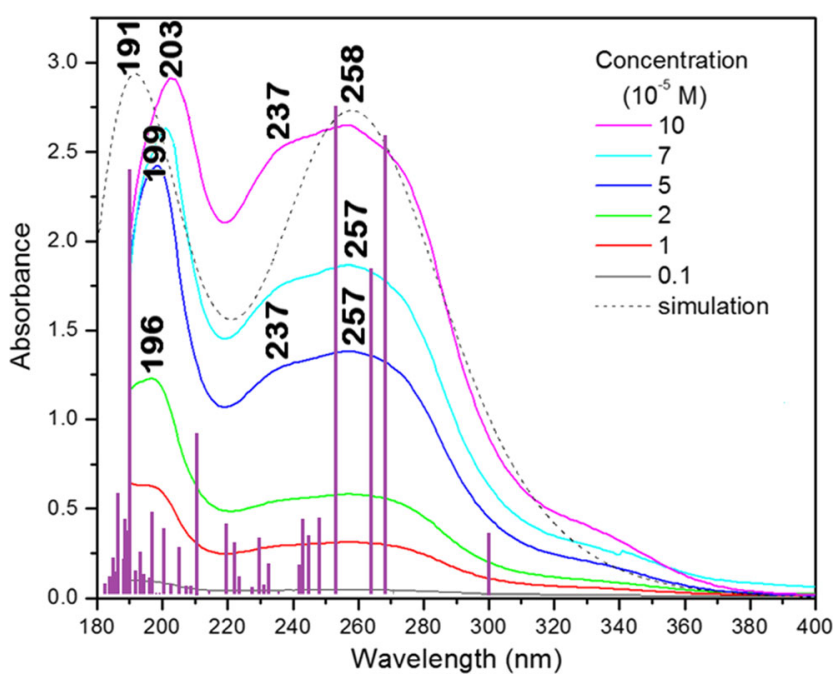

Fig. 3 Concentration dependence of the absorption spectra of IMT in water at room temperature. The simulated spectrum was calculated as Boltzmann population averaged spectra at room temperature of the nine most stable conformers in water. The stick spectrum corresponds to conformer (5)

measured at room temperature represents a thermal average over the UV-vis spectra of different conformers. The relative Gibbs energies $(\Delta \mathrm{G})$ and populations given in Table 2 suggest that the predominant contribution to UV-vis spectra of imatinib in water comes from the nine most stable imatinib monomers (5), (16), (13), (6), (3), (7), (10), (18) and (14) whose relative energies are within $0.49 \mathrm{kcal} \mathrm{mol}^{-1}$ and together constitute more than $68 \%$ of the total population.

The simulated spectrum shown in Fig. 3 was obtained as the sum of absorbance contributions of the nine most stable conformers in water, weighted by their Boltzmann population at room temperature. Calculated transitions energies, oscillator strengths and transition contributions are collected in Table 4. As shown in Fig. 3, the positions and intensities of the experimental bands are very well reproduced by calculations, including the molar absorption coefficient (see Fig. S1). We would like to mention that the use of the common B3LYP functional for excitation energies calculations leads to much larger discrepancies between experiment and theory. Thus, in that case, the largest calculated lambda is $281 \mathrm{~nm}$, that is, a difference of $24 \mathrm{~nm}$ from its experimental counterpart, in a range commonly encountered in the literature [91-94] for this property.

According to quantum chemical calculations, each of the nine most stable conformers of IMT give mainly four calculated absorption bands: around $190 \mathrm{~nm}$, due mainly to HOMO-6 $\rightarrow$ LUMO +4 transition; at $254 \mathrm{~nm}$, due to $\mathrm{HOMO}-2 \rightarrow \mathrm{LUMO}+1$ transition; at $265 \mathrm{~nm}$, due to HOMO $\rightarrow$ LUMO +1 transition and $270 \mathrm{~nm}$ due to HOMO $\rightarrow$ $\mathrm{LUMO}+1$ and $\mathrm{HOMO} \rightarrow \mathrm{LUMO}+2$ transitions.

The shapes of the molecular orbitals involved in the abovementioned transitions of (5) in water are shown in Fig. 4. The
Table 4 Time-dependent density functional theory (TD-DFT) CAMB3LYP/6-31G+(d,p)//B3LYP/6-31+G(d,p) calculated electronic transitions of the nine most stable conformers of IMT at room temperature in water

\begin{tabular}{|c|c|c|c|c|}
\hline Conformer & $\lambda(\mathrm{nm})$ & $\mathrm{f}^{\mathrm{a}}$ & Transitions & Contributions $\%{ }^{\mathrm{b}}$ \\
\hline \multirow[t]{7}{*}{ (5) } & 269.6 & 0.69 & $\mathrm{H} \rightarrow \mathrm{L}+1$ & 38.41 \\
\hline & & & $\mathrm{H} \rightarrow \mathrm{L}+2$ & 18.67 \\
\hline & 265.1 & 0.49 & $\mathrm{H} \rightarrow \mathrm{L}+2$ & 28.78 \\
\hline & & & $\mathrm{H} \rightarrow \mathrm{L}+1$ & 27.37 \\
\hline & & & $\mathrm{H} \rightarrow \mathrm{L}+3$ & 17.53 \\
\hline & 254.1 & 0.78 & $\mathrm{H}-2 \rightarrow \mathrm{L}+1$ & 20.97 \\
\hline & 189.6 & 0.64 & $\mathrm{H}-6 \rightarrow \mathrm{L}+4$ & 14.00 \\
\hline \multirow[t]{9}{*}{ (16) } & 269.7 & 0.65 & $\mathrm{H} \rightarrow \mathrm{L}+1$ & 37.64 \\
\hline & & & $\mathrm{H} \rightarrow \mathrm{L}+2$ & 16.14 \\
\hline & & & $\mathrm{H} \rightarrow \mathrm{L}+3$ & 15.81 \\
\hline & 265.2 & 0.48 & $\mathrm{H} \rightarrow \mathrm{L}+1$ & 28.11 \\
\hline & & & $\mathrm{H} \rightarrow \mathrm{L}+2$ & 24.82 \\
\hline & & & $\mathrm{H} \rightarrow \mathrm{L}+3$ & 20.99 \\
\hline & 253.6 & 0.78 & $\mathrm{H}-2 \rightarrow \mathrm{L}+1$ & 20.03 \\
\hline & & & $\mathrm{H}-3 \rightarrow \mathrm{L}+1$ & 13.31 \\
\hline & 189.6 & 0.41 & $\mathrm{H}-6 \rightarrow \mathrm{L}+4$ & 28.64 \\
\hline \multirow[t]{8}{*}{ (13) } & 269.9 & 0.65 & $\mathrm{H} \rightarrow \mathrm{L}+1$ & 39.60 \\
\hline & & & $\mathrm{H} \rightarrow \mathrm{L}+2$ & 15.03 \\
\hline & & & $\mathrm{H} \rightarrow \mathrm{L}+3$ & 14.85 \\
\hline & 265.3 & 0.49 & $\mathrm{H} \rightarrow \mathrm{L}+1$ & 26.35 \\
\hline & & & $\mathrm{H} \rightarrow \mathrm{L}+2$ & 25.93 \\
\hline & & & $\mathrm{H} \rightarrow \mathrm{L}+3$ & 21.86 \\
\hline & 253.7 & 0.78 & $\mathrm{H}-2 \rightarrow \mathrm{L}+1$ & 22.29 \\
\hline & 188.8 & 0.46 & $\mathrm{H}-6 \rightarrow \mathrm{L}+4$ & 15.26 \\
\hline \multirow[t]{8}{*}{ (6) } & 269.8 & 0.65 & $\mathrm{H} \rightarrow \mathrm{L}+1$ & 40.14 \\
\hline & & & $\mathrm{H} \rightarrow \mathrm{L}+2$ & 17.68 \\
\hline & & & $\mathrm{H} \rightarrow \mathrm{L}+7$ & 13.18 \\
\hline & 265.2 & 0.51 & $\mathrm{H} \rightarrow \mathrm{L}+2$ & 30.25 \\
\hline & & & $\mathrm{H} \rightarrow \mathrm{L}+1$ & 25.84 \\
\hline & & & $\mathrm{H} \rightarrow \mathrm{L}+3$ & 17.90 \\
\hline & 253.9 & 0.79 & $\mathrm{H}-2 \rightarrow \mathrm{L}+1$ & 22.95 \\
\hline & 189.6 & 0.77 & $\mathrm{H}-6 \rightarrow \mathrm{L}+4$ & 26.70 \\
\hline \multirow[t]{8}{*}{ (3) } & 269.7 & 0.65 & $\mathrm{H} \rightarrow \mathrm{L}+1$ & 39.44 \\
\hline & & & $\mathrm{H} \rightarrow \mathrm{L}+2$ & 18.14 \\
\hline & & & $\mathrm{H} \rightarrow \mathrm{L}+7$ & 13.17 \\
\hline & 265.2 & 0.51 & $\mathrm{H} \rightarrow \mathrm{L}+2$ & 29.70 \\
\hline & & & $\mathrm{H} \rightarrow \mathrm{L}+1$ & 26.51 \\
\hline & & & $\mathrm{H} \rightarrow \mathrm{L}+3$ & 17.81 \\
\hline & 253.8 & 0.79 & $\mathrm{H}-2 \rightarrow \mathrm{L}+1$ & 21.86 \\
\hline & 189.5 & 0.64 & $\mathrm{H}-6 \rightarrow \mathrm{L}+4$ & 25.21 \\
\hline \multirow[t]{6}{*}{ (7) } & 269.5 & 0.69 & $\mathrm{H} \rightarrow \mathrm{L}+1$ & 38.30 \\
\hline & & & $\mathrm{H} \rightarrow \mathrm{L}+2$ & 18.75 \\
\hline & 265.1 & 0.49 & $\mathrm{H} \rightarrow \mathrm{L}+2$ & 28.86 \\
\hline & & & $\mathrm{H} \rightarrow \mathrm{L}+1$ & 27.47 \\
\hline & & & $\mathrm{H} \rightarrow \mathrm{L}+3$ & 17.32 \\
\hline & 254.1 & 0.78 & $\mathrm{H}-2 \rightarrow \mathrm{L}+1$ & 22.23 \\
\hline
\end{tabular}


Table 4 (continued)

\begin{tabular}{|c|c|c|c|c|}
\hline Conformer & $\lambda(\mathrm{nm})$ & $f^{a}$ & Transitions & Contributions $\%{ }^{b}$ \\
\hline & 189.5 & 0.72 & $\mathrm{H}-6 \rightarrow \mathrm{L}+4$ & 20.16 \\
\hline \multirow[t]{7}{*}{ (10) } & 269.4 & 0.37 & $\mathrm{H} \rightarrow \mathrm{L}+1$ & 33.32 \\
\hline & & & $\mathrm{H} \rightarrow \mathrm{L}+2$ & 15.69 \\
\hline & & & $\mathrm{H} \rightarrow \mathrm{L}+6$ & 13.26 \\
\hline & 265.2 & 0.58 & $\mathrm{H} \rightarrow \mathrm{L}+1$ & 31.73 \\
\hline & & & $\mathrm{H} \rightarrow \mathrm{L}+2$ & 26.56 \\
\hline & & & $\mathrm{H} \rightarrow \mathrm{L}+3$ & 19.92 \\
\hline & 190.3 & 0.33 & $\mathrm{H}-6 \rightarrow \mathrm{L}+4$ & 13.88 \\
\hline \multirow[t]{8}{*}{ (18) } & 269.9 & 0.38 & $\mathrm{H} \rightarrow \mathrm{L}+1$ & 38.65 \\
\hline & & & $\mathrm{H} \rightarrow \mathrm{L}+2$ & 13.89 \\
\hline & & & $\mathrm{H} \rightarrow \mathrm{L}+6$ & 13.75 \\
\hline & 265.3 & 0.60 & $\mathrm{H} \rightarrow \mathrm{L}+1$ & 27.57 \\
\hline & & & $\mathrm{H} \rightarrow \mathrm{L}+2$ & 26.68 \\
\hline & & & $\mathrm{H} \rightarrow \mathrm{L}+3$ & 24.28 \\
\hline & 253.9 & 0.30 & $\mathrm{H}-2 \rightarrow \mathrm{L}+1$ & 30.23 \\
\hline & 189.5 & 0.26 & $\mathrm{H}-6 \rightarrow \mathrm{L}+4$ & 27.38 \\
\hline \multirow[t]{8}{*}{ (14) } & 269.9 & 0.38 & $\mathrm{H} \rightarrow \mathrm{L}+1$ & 38.65 \\
\hline & & & $\mathrm{H} \rightarrow \mathrm{L}+2$ & 13.89 \\
\hline & & & $\mathrm{H} \rightarrow \mathrm{L}+6$ & 13.75 \\
\hline & 265.3 & 0.60 & $\mathrm{H} \rightarrow \mathrm{L}+1$ & 27.57 \\
\hline & & & $\mathrm{H} \rightarrow \mathrm{L}+2$ & 26.68 \\
\hline & & & $\mathrm{H} \rightarrow \mathrm{L}+3$ & 24.28 \\
\hline & 253.9 & 0.31 & $\mathrm{H}-2 \rightarrow \mathrm{L}+1$ & 30.23 \\
\hline & 189.5 & 0.25 & $\mathrm{H}-6 \rightarrow \mathrm{L}+4$ & 27.84 \\
\hline
\end{tabular}

${ }^{a}$ Only transitions with $\mathrm{f}>0.25$ are included

${ }^{\mathrm{b}}$ Only contributions $>10 \%$ are included

highest energy observed transition (HOMO- $6 \rightarrow \mathrm{LUMO}+4$ ) at $190 \mathrm{~nm}$ is due mainly to a redistribution of electronic charge onto the phenyl moiety. The electronic transition HOMO-2 $\rightarrow$ LUMO +1 at $254 \mathrm{~nm}$ is a result of charge transfer from methylbenzene and piperazine rings to the phenyl group, concomitant with a redistribution of charge within

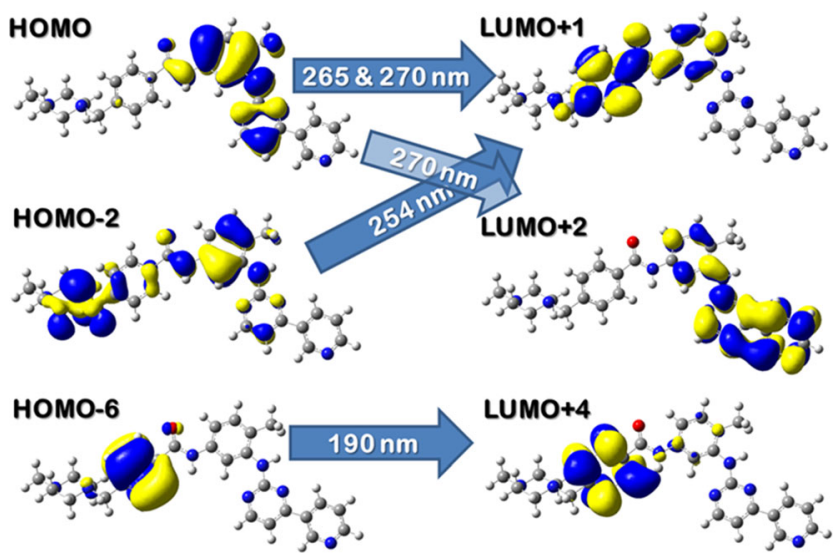

Fig. 4 CAM-B3LYP/6-31+G(d,p) calculated density plots of the molecular orbitals involved in the main electronic transitions of IMT conformer (5) in water the methylbenzene ring. This HOMO- $2 \rightarrow$ LUMO +1 electronic transition is most probably responsible for the absorption peak at $234-243 \mathrm{~nm}$ observed in water at different $\mathrm{pH}$ [17], at $238 \mathrm{~nm}$ in methanol [8,33], at $228 \mathrm{~nm}$ in ethanol [17] and at $230 \mathrm{~nm}$ in acetonitrile [50].

As seen in Fig. 4, the HOMO orbital is delocalized onto the methylbenzene, pyrimidine and amide group. The lowest energy electronic transitions HOMO $\rightarrow$ LUMO +1 and HOMO-LUMO +2 simulated in water at $258 \mathrm{~nm}$ and observed experimentally at $257 \mathrm{~nm}$ are due to charge transfer from the methylbenzene and pyrimidine groups to the phenyl ring. This is in agreement with Nardi et al. [50], who observed for compound 1 resulted from a combination of the methylbenzene and pyrimidine rings, an absorption peak in acetonitrile at $270 \mathrm{~nm}$.

It is worth mentioning here that the use of a continuum solvation model for calculating the electronic absorption spectrum of IMT could be questionable. However, very recent studies show that, for similarly large systems, the calculated excitation energies are influenced primarily by the geometry of the chromophore itself, with marginal contributions from specific solute-solvent interactions [79, 95], and that the implicit solvation model is sufficient to predict solvent effects with acceptable accuracy [89].

Further improvement of the agreement between experiment and theory could be achieved in three ways: (1) by calculating the vibronic structure of the absorption spectrum [96]; (2) by using the explicit solvation model, possibly within the QM/MM approach [97]; (3) reoptimizing the geometry of IMT using the CAM-B3LYP xc functional.

The possibility that the peak observed at $237 \mathrm{~nm}$ is part of the vibronic structure is ruled out since the difference between this peak and that seen at $257 \mathrm{~nm}$ corresponds to a vibrational mode with an energy of about $3,284 \mathrm{~cm}^{-1}$, which is not possible for IMT.

Because of the large size of the investigated molecule, the second possibility presumes very time consuming tasks, without any expected qualitative improvement $[79,95]$. The last option was, however, taken into account by using the same CAM-B3LYP/6-31+ G(d,p) level of theory for both geometry optimization and TD-DFT runs. The calculated excitation energies of the first three most intense transitions in the case of the most stable conformer in water (5) came closer to the experimental data by about $3 \mathrm{~nm}$, while the higher energy transitions are affected by less than $1 \mathrm{~nm}$. This is at the expense of a slight worsening observed in the reproduction of the relative intensities of the absorption bands.

\section{Conclusions}

Combining molecular mechanics and DFT quantum chemistry methods we were able to characterize 20 conformers of 
IMT, all of them being confirmed as minima on the PES. The relative Gibbs energies of the nine most stable IMT monomers in water were within $0.49 \mathrm{kcal} \mathrm{mol}^{-1}$ and together constitute more than $68 \%$ of the total population. Conformational data could be useful for further studies aimed at describing reliably the binding site of IMT or similar drugs within Bcr-Abl or other tyrosine kinases.

In water solution, IMT presents three UV-vis absorbance peaks in the range 195-203 nm, 237 and $257 \mathrm{~nm}$. A reliable assignment of the electronic transitions of IMT is provided based on the Boltzmann populations-averaged spectra of its conformers in water. The lowest energy absorption peak observed at $257 \mathrm{~nm}$ has its simulated counterpart at $258 \mathrm{~nm}$, and the transition is a result of charge transfer from the methylbenzene and pyrimidine groups to the phenyl moiety.

While the $6-31 \mathrm{G}(\mathrm{d})$ basis set seems to be an optimum choice for geometry optimizations of IMT and, presumably, for similar drugs, the $6-31+\mathrm{G}(\mathrm{d}, \mathrm{p})$ is required for relative energies and excitation energy calculations. Only by using the CAM-B3LYP long range corrected functional was it possible to reproduce quantitatively the lowest energy electronic absorption peak.

Based on the calculated thermochemical data, a value of 2.26 was estimated for the ratio of mole fractions $\mathrm{x}_{\alpha} / \mathrm{x}_{\beta}$ corresponding to the two known polymorphs of IMT, in excellent agreement with previously published experimental findings.

Acknowledgments The research undertaken for this article was conducted using the Babeș-Bolyai University Research infrastructure financed by the Romanian Government through the programme PN IICapacities - project title Integrated Network for Interdisciplinary Research (INIR), and the project MADECIP (POSCEE COD SMIS CSNR 48801/ 1862). V.C. highly acknowledges financial support from UEFISCDI PNII-RU-TE-2012-3-0227 grant. N.F.S. highly acknowledges financial support from the Babeș-Bolyai University through a Performance Scholarship during the academic year 2014-2015, contract number 36225-51/ 14.12.2014.

\section{Compliance with Ethical Standards}

Conflict of Interest The authors declare that they have no conflict of interest.

\section{References}

1. Demetri GD, von Mehren M, Blanke CD, Van den Abbeele AD, Eisenberg B, Roberts PJ, Heinrich MC, Tuveson DA, Singer S, Janicek M, Fletcher JA, Silverman SG, Silberman SL, Capdeville R, Kiese B, Peng B, Dimitrijevic S, Druker BJ, Corless C, Fletcher CDM, Joensuu H (2002) Efficacy and safety of imatinib mesylate in advanced gastrointestinal stromal tumors. N Engl J Med 347:472480

2. O'Brien SG, Guilhot F, Larson RA, Gathmann I, Baccarani M, Cervantes F, Cornelissen JJ, Fischer T, Hochhaus A, Hughes T, Lechner K, Nielsen JL, Rousselot P, Reiffers J, Saglio G, Shepherd J, Simonsson B, Gratwohl A, Goldman JM, Kantarjian H, Taylor K,
Verhoef G, Bolton AE, Capdeville R, Druker BJN (2003) Imatinib compared with interferon and low-dose cytarabine for newly diagnosed chronic-phase chronic myeloid leukemia. N Engl J Med 348: 994-1004

3. Druker BJ, Lydon NB (2000) Lessons learned from the development of an abl tyrosine kinase inhibitor for chronic myelogenous leukemia. J Clin Invest 105:3-7

4. Szakács Z, Béni S, Varga Z, Orfi L, Kéri G, Noszál B (2005) Acidbase ptofiling of imatinib (Gleevec) and its fragments. J Med Chem 48:249-255

5. Druker BJ (2008) Translation of the Philadelphia chromosome into therapy for CML. Blood 112:4804-4817

6. Muller BA (2009) Imatinib and its successors - how modern chemistry has changed drug development. Curr Pharm Des 15:120-133

7. Ksienski D (2011) Imatinib mesylate: past successes and future challenges in the treatment of gastrointestinal stromal tumors. Clin Med Insights Oncol 5:365-379

8. Al-Hadiya BMH, Bakheit AHH, Abd-Elgalil AA (2014) Imatinib mesylate. In: Brittain HG (ed) Profiles of drug substances, excipients and related methodology, vol 39. Elsevier, Amstersdam. pp 265-298

9. Schindler T, Bornmann W, Pellicena P, Miller WT, Clarkson B, Kuriyan J (2000) Structural mechanism for STI-571 inhibition of Abelson tyrosine kinase. Science 289:1938-1942

10. Zhang J, Yang PL, Gray NS (2009) Targeting cancer with small molecule kinase inhibitors. Nat Rev Cancer 9:28-39

11. Zhang J, Adrián FJ, Jahnke W, Cowan-Jacob SW, Li AG, Iacob RE, Sim T, Powers J, Dierks C, Sun F, Guo G-R, Ding Q, Okram B, Choi Y, Wojciechowski A, Deng X, Liu G, Fendrich G, Strauss A, Vajpai N, Grzesiek S, Tuntland T, Liu Y, Bursulaya B, Azam M, Manley PW, Engen JR, Daley GQ, Warmuth M, Gray NS (2010) Targeting Bcr-Abl by combining allosteric with ATP-binding-site inhibitors. Nature 463:501-507

12. Rubin BP, Schuetze SM, Eary JF, Norwood TH, Mirza S, Conrad EU, Bruckner JD (2002) Molecular targeting of platelet-derived growth factor B by Imatinib mesylate in a patient with metastatic dermatofibrosarcoma protuberans. J Clin Oncol 20:3586-3591

13. Maki RG, Awan RA, Dixon RH, Jhanwar S, Antonescu CR (2002) Differential sensitivity to imatinib of 2 patients with metastatic sarcoma arising from dermatofibrosarcoma protuberans. Int $\mathrm{J}$ Cancer 100:623-626

14. Halperin DM, Phan AT, Hoff AO, Aaron M, Yao JC, Hoff PM (2014) A phase I study of imatinib, dacarbazine, and capecitabine in advanced endocrine cancers. BMC Cancer 14:561

15. Galindo-Murillo R, Sandoval-Salinas ME, Barroso-Flores J (2014) In silico design of monomolecular drug carriers for the tyrosine kinase inhibitor drug imatinib based on calix- and thiacalix[n]arene host molecules: a DFT and molecular dynamics study. J Chem Theory Comput 10:825-834

16. Peng B, Lloyd P, Schran H (2005) Clinical pharmacokinetics of imatinib. Clin Pharmacokinet 44:879-894

17. Grante I, Actins A, Orola L (2014) Protonation effects on the UV/Vis absorption spectra of imatinib: a theoretical and experimental study. Spectrochim Acta A 129:326-332

18. Xiong YZ, Chen P-Y (2008) ONIOM DFT/PM3 calculation on the interaction between STI-571 and abelson tyrosine kinase. J Mol Model 14:1083-1086

19. Mucs D, Bryce RA, Bonnet P (2011) Application of shape-based and pharmacophore-based in silico screens for identification of Type II protein kinase inhibitors. J Comput Aided Mol Des 25:569-581

20. Dubey KD, Ojha RP (2011) Binding free energy calculation with QM/MM hybrid methods for Abl-Kinase inhibitor. J Biol Phys 37: 69-78

21. Aleksandrov A, Simonson T (2010) A molecular mechanics model for imatinib and imatinib:kinase binding. J Comput Chem 31:1550 1560 
22. Diculescu VC, Chiorcea-Paquima A-M, Tugulea L, Vivan M, Oliveira-Brett A-M (2009) Interaction of imatinib with liposomes: voltammetric and AFM characterization. Bioelectrochemistry 74: 278-288

23. Chen I-J, Foloppe N (2011) Is conformational sampling of drug-like molecules a solved problem? Drug Dev Res 72:85-94

24. Lopez-Vallejo F, Fragoso-Serrano M, Suarez-Ortiz GA, HernandezRojas AC, Cerda-García-Rojas CM, Pereda-Miranda R (2012) Vicinal ${ }^{1} \mathrm{H}-{ }^{1} \mathrm{H}$ NMR coupling constants from density functional theory as reliable tools for stereochemical analysis of highly flexible multichiral center molecules. J Org Chem 76:6057-6066

25. Pisani P, Piro P, Decherchi S, Bottegoni G, Sona D, Murino V, Rocchia W, Cavalli A (2014) Describing the conformational landscape of small organic molecules through gaussian mixtures in dihedral space. J Chem Theory Comput 10:2557-2568

26. Tezer N (2008) Conformation and tautomerizm of the 2-methyl-4pyridin-2'-yl-1,5-benzodiazepine molecule. An ab initio study. J Mol Model 14:11-20

27. Purushotham U, Vijay D, Narahari Sastry G (2012) A computational investigation and the conformational analysis of dimers, anions, cations, and zwitterions of L-phenylalanine. J Comput Chem 33:44-59

28. Barone V, Biczysko M, Bloino J, Puzzarini C (2013) Glycine conformers: a never-ending story? Phys Chem Chem Phys 15:13581363

29. Duarte L, Fausto R, Reva I (2014) Structural and spectroscopic characterization of E- and Z-isomers of azobenzene. Phys Chem Chem Phys 16:16919-16930

30. Araujo-Andrade C, Reva I, Fausto R (2014) Tetrazole acetic acid: tautomers, conformers, and isomerization. J Chem Phys 140:064306

31. Buczek A, Makowski M, Jewgiński M, Latajka R, Kupka T, Broda MA (2014) Toward engineering efficient peptidomimetics. Screening conformational landscape of two modified dehydroaminoacids. Biopolymers 101:28-40

32. Grillo D, Polla G, Vega D (2013) Conformational polymorphism on imatinib mesylate: grinding effects. J Pharm Sci 101:541-551

33. Srivastava A, Joshi BD, Tandon P, Ayala AP, Bansal AK, Grillo D (2013) Study of polymorphism in imatinib mesylate: a quantum chemical approach using electronic and vibrational spectra. Spectrochim Acta A 103:325-332

34. Liu Y-F, Wang C-L, Bai Y-J, Han N, Jiao J-P, Qi X-L (2008) A facile total synthesis of imatinib base and its analogues. Org Process Res Dev 12:490-495

35. Solassol F, Bressolle L, Philibert V, Charasson C, Astre F (2006) Liquid chromatography-electrospray mass spectrometry determination of imatinib and its main metabolite, N-desmethyl-Imatinib in human plasma. J Liq Chromatogr Relat Technol 29:2957-2974

36. Haouala A, Zanolari B, Rochat B, Montemurro M, Zaman K, Duchosal MA, Ris HB, Leyvraz S, Widmer N, Decosterd LA (2009) Therapeutic drug monitoring of the new targeted anticancer agents imatinib, nilotinib, dasatinib, sunitinib, sorafenib and lapatinib by LC tandem mass spectrometry. J Chromatogr B 877:1982-1996

37. Awidia A, Salem II, Najib N, Mefleha R, Tarawneh B (2010) Determination of imatinib plasma levels in patients with chronic myeloid leukemia by high performance liquid chromatography-ultraviolet detection and liquid chromatography-tandem mass spectrometry: methods' comparison. Leuk Res 34:714-717

38. Medenica M, Jancic B, Ivanovic D, Malenovic A (2004) Experimental design in reversed-phase high-performance liquid chromatographic analysis of imatinib mesylate and its impurity. J Chromatogr A 1031:243-248

39. Velpandian T, Mathur R, Agarwal NK, Arora B, Kumar L, Gupta SK (2004) Development and validation of a simple liquid chromatographic method with ultraviolet detection for the determination of imatinib in biological samples. J Chromatogr B 804:431-434

40. Roos LO, Jos HB, Jan HM, van Olaf T (2007) Determination of imatinib mesylate and its main metabolite (CGP74588) in human plasma and murine specimens by ion-pairing reversed-phase highperformance liquid chromatography. Biomed Chromatogr 21:747754

41. De Francia S, D'Avolio A, De Martino F, Pirro E, Baietto L, Siccardi M, Simiele M, Racca S, Saglio G, Di Carlo F, Di Perri G (2009) New HPLC-MS method for the simultaneous quantification of the antileukemia drugs imatinib, dasatinib, and nilotinib in human plasma. J Chromatogr B 877:1721-1726

42. Roth O, Spreux-Varoquaux O, Bouchet $S$, Rousselot $P$, Castaigne $S$, Rigaudeau S, Raggueneau V, Therond P, Devillier P, Molimard M, Maneglier B (2010) Imatinib assay by HPLC with photodiode-array UV detection in plasma from patients with chronic myeloid leukemia: Comparison with LC-MS/MS. Clin Chim Acta 411:140-146

43. Alkharfy KM, Khan RM, Al-Asmari M, Alhadeyah BH, Ahmad A (2013) Quantitative determination of imatinib stability under various stress conditions. J Pharm Bioallied Sci 5:49-52

44. Parise RA, Ramanathan RK, Hayes MJ, Egorin MJ (2003) Liquid chromatographic-mass spectrometric assay for quantitation of imatinib and its main metabolite (CGP 74588) in plasma. J Chromatogr B 791:39-44

45. Flores RJ, Nevado N, Salcedo C, Díaz C (2005) Nonaqueous capillary electrophoresis method for the analysis of gleevec and its main metabolite in human urine. J Chromatogr A 1068:175-182

46. Fitos I, Visy J, Zsila F, Mády G, Simonyi M (2006) Selective binding of imatinib to the genetic variants of human $\alpha_{1}$-acid glycoprotein. Biochim Biophys Acta 1760:1704-1712

47. Bende G, Kollipara S, Sekar V, Saha R (2008) UVspectrophotometric determination of imatinib mesylate and its application in solubility studies. Pharmazie 63:641-645

48. Patil SR, Nandre JP, Jadhav D, Bothra S, Sahoo SK, Devi M, Pradeep CP, Mahulikar PP, Patil UD (2014) Imatinib intermediate as a two in one dual channel sensor for the recognition of $\mathrm{Cu}^{2+}$ and $\mathrm{I}^{-}$ions in aqueous media and its practical applications. Dalton Trans 43:13299

49. Agafonov RV, Wilson C, Otten R, Buosi V, Kern D (2014) Energetic dissection of Gleevec's selectivity toward human tyrosine kinases. Nat Struct Mol Biol 21:848-853

50. Nardi G, Lhiaubet-Vallet V, Miranda MA (2014) Photosensitization by Imatinib. A photochemical and photobiological study of the drug and its substructures. Chem Res Toxicol 27:1990-1995

51. Martens-Lobenhoffer J, Bode-Böger SM (2005) Determination of levetiracetam in human plasma with minimal sample pretreatment. J Chromatogr B 819:197-200

52. Guo T, Oswald LM, Mendu DR, Soldin SJ (2007) Determination of levetiracetam in human plasma/serum/saliva by liquid chromatography-electrospray tandem mass spectrometry. Clin Chim Acta 375:115-118

53. Matar KM (2008) Quantification of levetiracetam in human plasma by liquid chromatography-tandem mass spectrometry: application to therapeutic drug monitoring. J Pharm Biomed Anal 48:822-828

54. Shi Y, Xia Z, Zhang J, Best R, Wu C, Ponder JW, Ren P (2013) Polarizable atomic multipole-based AMOEBA force field for proteins. J Chem Theory Comput 9:4046-4063

55. Halgren TA (1996) Merck molecular force field. I. Basis, form, scope, parameterization, and performance of MMFF94. J Comput Chem 17:490-519

56. Halgren TA (1996) Merck molecular force field. II. MMFF94 van der Waals and electrostatic parameters for intermolecular interactions. J Comput Chem 17:520-552

57. Halgren TA (1996) Merck molecular force field. III. molecular geometries and vibrational frequencies for MMFF94. J Comput Chem 17:553-586

58. Halgren TA (1996) Merck molecular force field. IV. Conformational energies and geometries for MMFF94*. J Comput Chem 17:587-615

59. Becke AD (1993) Density-functional thermochemistry. III. The role of exact exchange. J Chem Phys 98:5648-5652 
60. Lee C, Yang W, Parr RG (1988) Development of the Colle-Salvetti correlation-energy formula into a functional of the electron density. Phys Rev B 37:785-789

61. Vosko SH, Wilk L, Nusair M (1980) Accurate spin-dependent electron liquid correlation energies for local spin density calculations: a critical analysis. Can J Phys 58:1200-1211

62. Stephens PJ, Devlin FJ, Chabalowski CF, Frisch MJ (1994) Ab initio calculation of vibrational absorption and circular dichroism spectra using density functional force fields. J Phys Chem 98:11623-11627

63. Hehre WJ, Ditchfield R, Pople JA (1972) Self — consistent molecular orbital methods. XII. further extensions of gaussian - type basis sets for use in molecular orbital studies of organic molecules. J Chem Phys 56:2257-2261

64. Tomasi J, Mennucci B, Cammi R (2005) Quantum mechanical continuum solvation models. Chem Rev 105:2999-3093

65. Frisch MJ, Trucks GW, Schlegel HB, Scuseria GE, Robb MA, Cheeseman JR, Scalmani G, Barone V, Mennucci B, Petersson GA, Nakatsuji H, Caricato M, Li X, Hratchian HP, Izmaylov AF, Bloino J, Zheng G, Sonnenberg JL, Hada M, Ehara M, Toyota K, Fukuda R, Hasegawa J, Ishida M, Nakajima T, Honda Y, Kitao O, Nakai H, Vreven T, Montgomery JA Jr, Peralta JE, Ogliaro F, Bearpark M, Heyd JJ, Brothers E, Kudin KN, Staroverov VN, Keith T, Kobayashi R, Normand J, Raghavachari K, Rendell A, Burant JC, Iyengar SS, Tomasi J, Cossi M, Rega N, Millam JM, Klene M, Knox JE, Cross JB, Bakken V, Adamo C, Jaramillo J, Gomperts R, Stratmann RE, Yazyev O, Austin AJ, Cammi R, Pomelli C, Ochterski JW, Martin RL, Morokuma K, Zakrzewski VG, Voth GA, Salvador P, Dannenberg JJ, Dapprich S, Daniels AD, Farkas O, Foresman JB, Ortiz JV, Cioslowski J, Fox DJ (2010) GAUSSIAN 09 C.01. Wallingford, Gaussian Inc

66. Willoughby PH, Jansma MJ, Hoye TR (2014) A guide to smallmolecule structure assignment through computation of $\left({ }^{1} \mathrm{H}\right.$ and ${ }^{13}$ C) NMR chemical shifts. Nat Protoc 9:643-660

67. Casida MR, Jamorski C, Casida KC, Salahub DR (1988) Molecular excitation energies to high-lying bound states from time-dependent density-functional response theory: characterization and correction of the time-dependent local density approximation ionization threshold. J Chem Phys 108:4439-4449

68. Yanai T, Tew D, Handy N (2004) A new hybrid exchange-correlation functional using the Coulomb-attenuating method (CAM-B3LYP). Chem Phys Lett 393:51-57

69. Macrae CF, Edgington PR, McCabe P, Pidcock E, Shields GP, Taylor R, Rowler M, van de Streek J (2006) Mercury: visualization and analysis of crystal structures. J Appl Crystallogr 39:453-457

70. Molegro Molecular Viewer, version 2.5. Molegro ApS; Aarhus, Denmark: 2012

71. Nagar B, Bornmann W, Pellicena P, Schindler T, Veach DR, Miller WT, Clarkson B, Kuriyan J (2002) Crystal structures of the kinase domain of c-Abl in complex with the small molecule inhibitors PD173955 and imatinib (STI-571). Cancer Res 62:4236-4243

72. Moss GP (1996) Basic terminology of stereochemistry. Pure Appl Chem 68:2193-2222

73. Cacela C, Baudot A, Duarte ML, Matos-Beja AM, Ramos Silva M, Paixao JA, Fausto R (2003) Low temperature polymorphism in 3amino-1-propanol. J Mol Struct 649:143-153

74. Almeida DRP, Pisterzi LF, Chass GA, Torday LL, Varro A, Papp JG, Csizmadia IG (2002) Density functional molecular study on the full conformational space of the $S$-4-(2-Hydroxypropoxy)carbazol fragment of carvedilol (1-(9H-Carbazol-4-yloxy)-3-[2-(2methoxyphenoxy) ethylamino]-2-propanol) in vacuum and in different solvent media. J Phys Chem A 106:10423-10436

75. Sahai MA, Fejer SN, Viskolcz B, Pai EF, Csizmadia IG (2006) Firstprinciple computational study on the full conformational space of Lthreonine diamide, the energetic stability of cis and trans isomers. $\mathrm{J}$ Phys Chem A 110:11527-11536
76. Juaristi E, Notario R (2013) Computational reexamination of the eclipsed conformation in cis-2-tert-butyl-5-(tert-butylsulfonyl)-1,3dioxane. Struct Chem 24:1855-1862

77. Perrier A, Maurel F, Browne WR, Jacquemin D (2013) Full ring closing in a diarylethene hexamer: insights from theory. Chem Commun 49:4247-4249

78. Suresh Kumar NV, Singh H (2014) Density functional theory based study on cis-trans isomerism of the amide bond in homodimers of $\beta^{2}$, ${ }^{3}$ - and $\beta^{3}$-Substituted Homoproline. J Phys Chem A 118:2120-2137

79. Chibani S, Jacquemin D, Laurent AD (2014) Modelling solvent effects on the absorption and emission spectra of constrained cyanines with both implicit and explicit QM/EFP models. Comput Theor Chem 1040-1041:321-327

80. Sjoqvist J, Gonzalez-Cano RC, Lopez Navarrete JT, Casado J, Ruiz Delgado MC, Linaresa M, Norman P (2014) A combined MD/QM and experimental exploration of conformational richness in branched oligothiophenes. Phys Chem Chem Phys 16:24841-24852

81. Poling BE, Prausnitz JM, O'Connell JP (2001) The properties of gases and liquids. McGraw-Hill, New York

82. Klamt A, Eckert F (2000) COSMO-RS: a novel and efficient method for the a priori prediction of thermophysical data of liquids. Fluid Phase Equilib 172:43-72

83. Reichardt C (2007) Solvents and solvent effects: an introduction. Org Process Res Dev 11:105-113

84. Sancho MI, Almandoz MC, Blanco SE, Castro EA (2011) Spectroscopic study of solvent effects on the electronic absorption spectra of flavone and 7-hydroxyflavone in neat and binary solvent mixtures. Int J Mol Sci 12:8895-8912

85. Fukuda R, Ehara M (2013) Mechanisms for solvatochromic shifts of free-base porphine studied with polarizable continuum models and explicit solute-solvent interactions. J Chem Theory Comput 9:470 480

86. Etienne T, Michaux C, Monari A, Assfeld X, Perpète EA (2014) Theoretical computation of betain B30 solvatochromism using a polarizable continuum model. Dyes Pigments 100:24-31

87. Etienne T, Gattuso H, Monari A, Assfeld X (2014) QM/MM modeling of Harmane cation fluorescence spectrum in water solution and interacting with DNA. Comput Theor Chem 1040-1041:367-372

88. Etienne T, Assfeld X, Monari A (2014) Toward a quantitative assessment of electronic transitions' charge-transfer character. J Chem Theory Comput 10:3896-3905

89. Kelterer A-M, Uray G, Fabian WMF (2014) Long wavelength absorbing carbostyrils as test cases for different TDDFT procedures and solvent models. J Mol Model 20:2217

90. Peach MJG, Benfield P, Helgaker T, Tozer DJ (2008) Excitation energies in density functional theory: an evaluation and a diagnostic test. J Chem Phys 128:044118

91. Charaf-Eddin A, Planchat A, Mennucci B, Adamo C, Jacquemin D (2013) Choosing a functional for computing absorption and fluorescence band shapes with TD-DFT. J Chem Theory Comput 9:27492760

92. Oltean M, Calborean A, Mile G, Vidrighin M, Iosin M, Leopold L, Maniu D, Leopold N, Chiș V (2012) Absorption spectra of PTCDI: a combined UV-Vis and TD-DFT study. Spectrochim Acta A 97:703710

93. Leang SS, Zahariev F, Gordon MS (2012) Benchmarking the performance of time-dependent density functional methods. J Chem Phys 136:104101

94. De Mitri N, Prampolini G, Monti S, Barone V (2014) Structural, dynamic and photophysical properties of a fluorescent dye incorporated in an amorphous hydrophobic polymer bundle. Phys Chem Chem Phys 16:16573-16587

95. Almandoz MC, Sancho MI, Duchowicz PR, Blanco SE (2014) UVVis spectroscopic study and DFT calculation on the solvent effect of trimethoprim in neat solvents and aqueous mixtures. Spectrochim Acta A 129:52-60 
96. Barone V, Bloino J, Biczysko M, Santoro F (2009) Fully integrated approach to compute vibrationally resolved optical spectra: from small molecules to macrosystems. J Chem Theory Comput 5:540 554
97. Corchado JC, Sánchez ML, Galván IF, Martín ME, Muñoz-Losa A, Barata-Morgado R, Aguilar MA (2014) Theoretical study of solvent effects on the ground and low-lying excited free energy surfaces of a push-pull substituted azobenzene. J Phys Chem B 118:12518-12530 